\title{
Removal and Survival of Fecal Indicators in a Constructed Wetland after UASB Pre-Treatment
}

\author{
Fabio Conti ${ }^{1}\left(\mathbb{D}\right.$, Elena Cristina Rada ${ }^{1, *(\mathbb{D})}$, Paolo Viotti ${ }^{2}(\mathbb{D})$ and Massimo Raboni ${ }^{3}$ \\ 1 Department of Theoretical and Applied Sciences, Insubria University, 21100 Varese, Italy; \\ fabio.conti@uninsubria.it \\ 2 Department of Civil and Environmental Engineering, Sapienza Università di Roma, 00184 Roma, Italy; \\ paolo.viotti@uniroma1.it \\ 3 Department Hydraulics and Environmental Engineering, University of Pavia, 27100 Pavia, Italy; \\ massimo.raboni@gmail.com \\ * Correspondence: elena.rada@uninsubria.it; Tel.: +39-0332-218782
}

Citation: Conti, F.; Rada, E.C.; Viotti, P.; Raboni, M. Removal and Survival of Fecal Indicators in a Constructed Wetland after UASB Pre-Treatment. Sustainability 2021, 13, 9302. https:// doi.org/10.3390/su13169302

Academic Editor: Danilo Spasiano

Received: 16 June 2021

Accepted: 17 August 2021

Published: 19 August 2021

Publisher's Note: MDPI stays neutral with regard to jurisdictional claims in published maps and institutional affiliations.

Copyright: () 2021 by the authors. Licensee MDPI, Basel, Switzerland. This article is an open access article distributed under the terms and conditions of the Creative Commons Attribution (CC BY) license (https:// creativecommons.org/licenses/by/ $4.0 /)$.
Abstract: The experimentation plant, based on a sub-surface horizontal flow phytodepuration (SSHFP) unit with a pre-treatment by an upflow anaerobic sludge blanket (UASB) reactor, proved valuable in treating the sewage of a small rural community located in north Brazil. During a sixmonth trial, the plant achieved an average removal efficiency of $98.2 \%$ (1.74 log removal) for fecal coliforms (FC) and 96.0\% (1.40 log removal) for Enterococci (EN), as well as $95.6 \%$ for $\mathrm{BOD}_{5}, 91.0 \%$ for COD,00 and $95.4 \%$ for suspended solids (SS). The contribution of the UASB reactor to this overall performance was very significant as, alone, it achieved a yield of $62.7 \%$ for $\mathrm{FC}$ and $60 \%$ for $\mathrm{EN}$, in addition to $65.2 \%$ for $\mathrm{BOD}_{5}$ and $65.0 \%$ for SS. EN was chosen, in addition to $\mathrm{FC}$, because of its higher specificity and strong environmental persistence, leading to an increased risk to human health. In fact, the experimental results confirmed its lower removal efficiency compared to FC. The mechanical and biological mechanisms that led to such a removal efficiency of the two fecal indicators (FIs) are outlined in the article. The same mechanisms led to a good level of equivalence between the removal efficiency of the two FIs with the removal efficiency of $\mathrm{SS}$ and $\mathrm{BOD}_{5}$, for both the whole plant and the UASB reactor alone. The research demonstrated the close correlation between the concentrations of EN and FC for the plant effluent. This correlation can be explained by the following mathematical expression of the regression $\operatorname{line} \log E N=0.2571 \log F C+3.5301$, with a coefficient of determination $\mathrm{R}^{2}=0.912$. This implies that the concentration of the more specific indicator EN could be calculated, with acceptable approximation, from the simple analysis of FC and vice versa. The experimental plant brought important health benefits to the local population. In particular, there were no significant odor emissions; moreover, the risk of fecal pathogenic diseases was drastically reduced; finally, there was no proliferation of insects and other disease vectors, due to the absence of stagnant or semi-stagnant water exposed to the atmosphere.

Keywords: constructed wetland; enterococci; fecal indicators; fecal coliforms; phytodepuration; sewage treatment; UASB

\section{Introduction}

Sewage is the main cause of fecal contamination of water bodies and, as such, it constitutes a serious health risk due to pathogenic microorganisms excreted by infected people. These infectious vectors belong to the huge kingdoms of bacteria, protozoa, and viruses. The main pathogen microorganisms and relative diseases to humans, due to fecal contamination, are summarized in Table 1.

Helminths, which, in effect, are pluricellular parasitic worms, are often associated with the microorganisms' microcosm because of their microscopic eggs and larvae that cause diseases. 
These pathogens can occur in water and wastewaters in very low concentrations, thus, making their identification difficult. For this reason, the microbiological analyses commonly refer to FIs, which are non-pathogen microorganisms that indicate the possible presence of pathogens of fecal origin. Thus, if indicators are present, it can be deduced, on a probabilistic base, that pathogens may also be present. The level of probability depends on the concentration of FIs.

Table 1. Main pathogen microorganisms and relative diseases to humans [1].

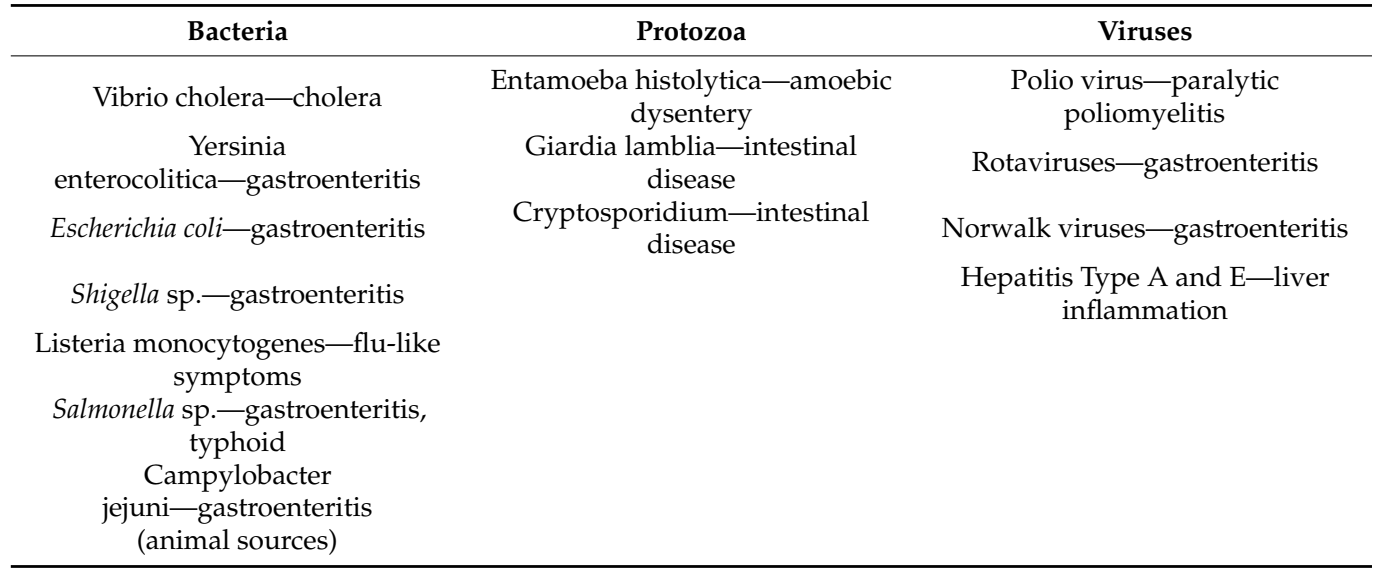

The criteria to be satisfied by ideal FIs are [2]:

- Universally present in large numbers in the feces of humans and warm-blooded animals;

- Readily detected by simple methods;

- Do not grow in natural waters;

- Persistence in water and removal by water treatment similar to waterborne pathogens.

It is important to state that no indicator fully meets all the listed conditions. The effort undertaken is to identify the most appropriate indicator on a case by case basis (type of pathogen, source, environment, physical-chemical conditions) in order to make its probabilistic correlation with the pathogenic agents, as reliable as possible.

FC is the most popular indicator, having been used for many years all over the world. FC are also defined as thermotolerant coliforms, due to their ability to ferment lactose with the production of gas and acid at the temperature of $44.5 \pm 0.2{ }^{\circ} \mathrm{C}$ and with an incubation time of 24-48 h. FC are facultative, rod-shaped, Gram-negative, non-spore-forming bacteria. Contaminated food is the main vector of fecal pathogens, while recreational waters and, above all, drinking water are common sources in developing countries [3].

Several studies have proven that a few members of the FC community are not strictly specific to sewage. [4-7]. Thus, E. coli and EN are now considered, by the scientific community, to be the most specific FIs.

E. coli is a group of facultative, rod-shaped bacteria, which are members of the FC community. They colonize the gastro-intestinal tract of all humans and warm-blooded animals [8]. Thus, they are commonly harmless and even help to keep the digestive tract healthy, but some strains have proven to be pathogenic, in particular E. coli O157:H7, which is responsible for diseases involving gastrointestinal and urological systems.

The EN belongs to the Enterococcaceae family, which consists of several species present in human and animal gastrointestinal microflora [9], even though they constitute a very small share. EN, similarly to $E$. coli, are remarkably resilient bacteria, capable of surviving in a wide range of $\mathrm{pH}$ levels and temperatures, and even against antimicrobial agents [10-12]. Likely, this is the reason of their broad occurrence in soils, water, and food. Due to their persistence in the environment, the presence of EN is adopted by many regulations as indicators of human fecal pollution in water.

Sewage treatment plants are effective in the removal of physico-chemical pollutants such as TOC, COD, BOD 5 , SS, nutrients, and others [13-16], as well as microbiological 
indicators $[3,17,18]$. With regard to the latter, the scientific literature gives abundant information about the concentrations of TC and FC in raw sewage and downstream of the different treatment units. TC are found in raw sewage in the range of $10^{7}-10^{9} \mathrm{CFU}$ $100 \mathrm{~mL}^{-1}$, while FC ranges between $10^{6}-10^{8} \mathrm{CFU} 100 \mathrm{~mL}^{-1}$ [13,17-21]. Of course, from case to case, the concentration is influenced by the sewage "strength". Mechanical-biological treatment can remove these indicators by 90-99\% (1-2 log removal) [13-22]. A significant increase of up to $99.999 \%$ ( 5 log removal) can be achieved only by a final disinfection process (UV or chemical disinfectants such as ozone, chlorine dioxide, chlorine or sodium hypochlorite, peracetic acid) that, in developed countries, becomes mandatory in the cases of wastewater reuse or discharge into recreational waters [23].

With reference to the more specific fecal indicators, E. coli and EN, the scientific databases give a lot of data on their presence in waterbodies and the related health risks, while less information is available about their fate in the various types of sewage treatment plants $[18,24]$. By investigating eight full-scale activated sludge plants, E. coli was found in raw sewage at $6 \times 10^{6}-7 \times 10^{6} \mathrm{CFU} 100 \mathrm{~mL}^{-1}$ and the average removal efficiency was $36.7 \%$ (0.2 log removal) for primary treatment and $94.2 \%$ (1.24 log removal) for the whole plants, excluding disinfection [18]. In two biological sewage treatment plants (preliminary treatment followed by activated sludge process) in the Netherlands, E. coli and EN were detected in raw sewage at $10^{6} \mathrm{CFU} 100 \mathrm{~mL}^{-1}$ and $10^{5} \mathrm{CFU} 100 \mathrm{~mL}^{-1}$, respectively, while the whole average removal efficiency was $94.4-97.8 \%$ for E. coli and $95.5-98.8 \%$ for EN [25]. EN were also found in raw sewage of four activated sludge plants at 5.19-6.53 log UFC $100 \mathrm{~mL}^{-1}$ and at $3.01-5.11 \log$ UFC $100 \mathrm{~mL}^{-1}$ in the effluent of the biological stage. The corresponding removal efficiency ranged between $83.4-99.8 \%$ (0.78-2.70 log removal), where the best values refer to the plant with the highest hydraulic retention time (HRT) (2.2 days) and the worst to the plant with a very short retention time $(6 \mathrm{~h})$ [26].

Constructed wetlands (CW) are mainly used for sewage treatment of small communities, but there are also applications in industrial wastewaters and leachate of urban waste landfills [27-30]. In sewage treatment, CW can reduce $84 \%$ of total coliform, $96 \%$ of FIs, and $89 \%$ of EN [31]. A literature survey of sixty CW with emergent macrophytes revealed that the removal of enteric bacteria is comparable with that of conventional mechanicalbiological treatment, where typical reductions are 90-99\% (1-2 log reduction) [32-34]. However, the result is significantly influenced by various factors, including the type of constructed wetland (surface flow, sub-surface flow, hybrid flow), the HRT, and the efficiency of pre-treatment [35-38].

A CW is an excellent solution for the treatment of sewage of small rural communities due to its simplicity of construction and operation and the very favorable cost-effectiveness ratio. Furthermore, the high HRT determines a leveling of the incoming load peaks (hydraulic and organic), giving stability to the treatment process [39]. However, the sewage before being fed to these natural treatment systems needs a pre-treatment in order to remove coarse materials, grit, and settleable solids. The contribution of several types of macrophytes to the efficiency is well highlighted in the literature $[40,41]$.

The present research focused on a CW with UASB pre-treatment serving a small rural community located in a tropical area of north Brazil.

UASB reactors were originally applied to the treatment of industrial wastewaters with a high concentration of biodegradable organics, such as, for example, those from sugar and dairy industries, livestock, distilleries, slaughterhouses, breweries, pulp and paper mills, and food industries [42-45]. These applications were (and still are today) amply justified by the significant energy recovery from the biogas produced. More recently, several applications of UASB in sewage treatment were carried out in Brazil, Colombia, and India [46-50], as well as in other countries with tropical or sub-tropical climates such as the UAE, Iran, Angola, Indonesia, Egypt, Palestine, Jordan, Thailand, and others [21,50-52]. In developing countries, UASB is often the only treatment stage, but the importance of an additional oxidative biological treatment is widely acknowledged. 
The sustainability of a sewage treatment plant for small rural communities in developing countries requires negligible maintenance, very low power consumption, ease of operation, and, above all, it should lead to an effective improvement in the health of the population. The exposure of the local population is mainly related to the microbiological risk, considering the fact that these plants almost always lack the final disinfection and the treated effluent (or the receiving water body) is often reused for irrigation and other practices. It is, therefore, important that the treatment demonstrates its ability to effectively remove pathogenic microorganisms. For this reason, the present research focused on the fate of fecal indicators microorganisms along the plant. In particular, fecal FC and $\mathrm{EN}$ were chosen as reference parameters; the latter due to its greater persistence in the natural environment.

\section{Materials and Methods}

Figure 1 shows the simplified diagram of the sewage treatment plant serving a rural community of 1650 inhabitants, with a daily flow rate of $220 \mathrm{~m}^{3} \mathrm{~d}^{-1}\left(133 \mathrm{~L} \mathrm{capita}^{-1} \mathrm{~d}^{-1}\right)$.

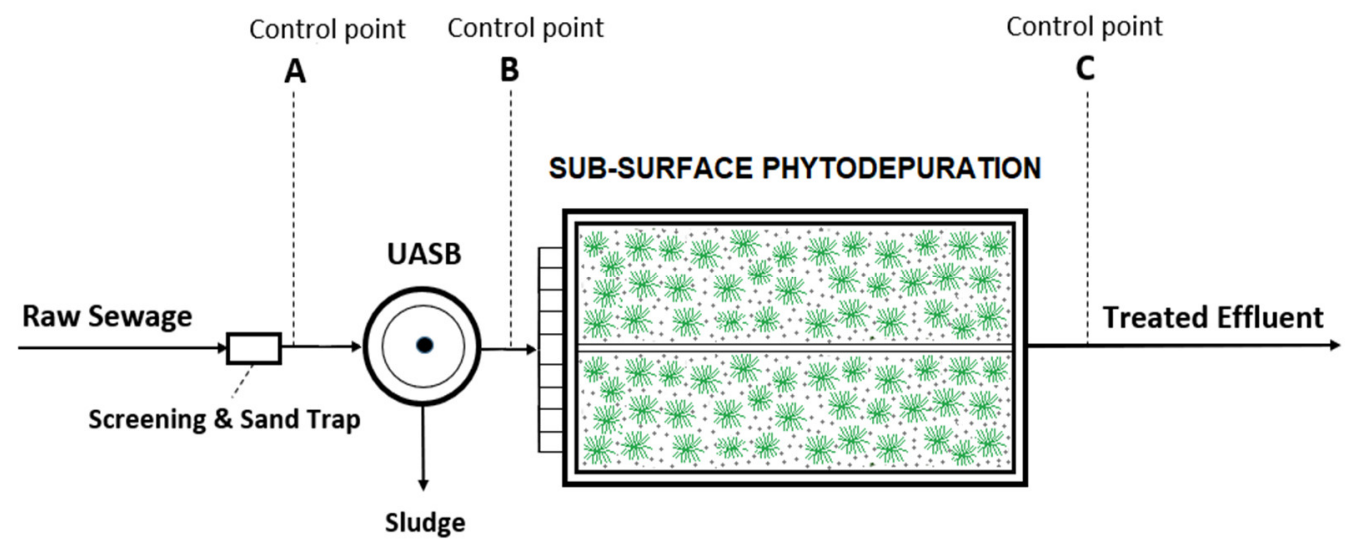

Figure 1. Simplified diagram of the treatment plant.

The raw sewage is pre-treated (screening and grit trapping) before being fed to a UASB reactor followed by a SSHFP unit with emergent macrophytes of the species Typha domingensis, a perennial herbaceous vegetable that grows easily in temperate and tropical climates. This common vegetable is signaled for its capacity to significantly reduce the content of enterobacteria in water [53].

The volume of the UASB reactor is $125 \mathrm{~m}^{3}$, equally subdivided into a sludge zone (on the bottom) and a sedimentation zone (on the upper part of the reactor). The pre-treated sewage is uniformly distributed on the bottom by means of a radial array of perforated pipes and flows upwards, at first crossing the granulated activated sludge zone and then the sedimentation zone. The average HRT amounts to $13.6 \mathrm{~h}$. In the first zone, an anaerobic biodegradative activity is carried out with the production of biogas (extracted from the top cover), while in the upper section, with a larger diameter, the sedimentation of finer SS is achieved. The stabilized sludge is periodically extracted from the bottom.

The SSHFP consists of two parallel lines with $2200 \mathrm{~m}^{2}$ total surface and $0.80 \mathrm{~m}$ water height. The porous media consists of coarse stones $(5-10 \mathrm{~cm})$. The base and side walls of the CW are fully waterproofed by a layer of compacted clay $(50 \mathrm{~cm})$ overlaid with a HDPE membrane. Average empty bed hydraulic retention time amounts to 8 days.

The research aimed to:

- Verify the efficiency of the whole treatment process and also of individual stages with regard to FC and $\mathrm{EN}$ (as well as the common physico-chemical parameters, $\mathrm{BOD}_{5}$, COD, SS) through a statistical analysis of collected data;

- Verify the relationship among FIs and the most representative physico-chemical parameters in order to evaluate a possible equivalency correlation. 
- Verify the sustainability of a statistical relationship between the concentrations of FC and EN by reconstructing their mathematical correlation with the relative coefficient of determination $\mathrm{R}^{2}$;

- Overall, verify the validity of the experimental treatment technology from the environmental and sanitary point of view.

The efficiency was evaluated along 6 months of continuous operation of the plant. In this period, sixty daily average water samples were collected at each of the following three points (see Figure 1):

- Point A: raw sewage (after preliminary treatment);

- Point B: effluent of UASB reactor;

- $\quad$ Point C: effluent of SSHFP (whole plant effluent).

Total samples analyzed: 180

The following parameters were analyzed: fecal coliforms, EN, BOD 5, COD, SS, and temperature. as follows:

Removal efficiencies of each treatment unit and of the whole plant were calculated

- Removal efficiency of the whole plant $\eta$ tot $=\left(X_{A}-X_{C}\right) / X_{A}$;

- Removal efficiency of UASB reactor $\eta 1=\left(X_{A}-X_{B}\right) / X_{A}$;

- Removal efficiency of phytodepuration unit $\eta 2=\left(X_{B}-X_{C}\right) / X_{B}$;

- $\quad$ Share of total efficiency ( $\eta$ tot) given by UASB reactor $\eta 1^{*}=\eta 1=\left(X_{A}-X_{B}\right) / X_{A}$;

- $\quad$ Share of total efficiency ( $\eta$ tot) given by phytodepuration unit $\eta 2^{*}=\left(X_{B}-X_{C}\right) / X_{A}$;

- $\quad \eta$ tot $=\eta 1^{*}+\eta 2^{*}$;

where $X$ represents each tested parameter and the subscript letters refer to each of the three sampling points.

- $\mathrm{X}_{\mathrm{A}}$ is the value of the generic parameter at position A (raw sewage);

- $\quad X_{B}$ at position B (UASB outlet = SSHFP inlet);

- $X_{C}$ at position C (SSHFP outlet = final effluent).

Sampling and analysis were done in compliance with the Standard Methods for the Examination of Water and Wastewater, Centennial Edition 2005, joint publication of the American Public Health Association, the American Water Works Association, and the Water Environment Federation [54].

\section{Results and Discussion}

\subsection{Raw Sewage Quality}

Table 1 shows the statistical data concerning the raw sewage quality, as measured in the experimental period. The data are typical of a "high-strength" sewage, due to the low per capita water consumption (about $140 \mathrm{~L} \mathrm{~d}^{-1}$ per capita). This is well shown by the average values of $\mathrm{BOD}_{5}=418.5 \mathrm{mg} \mathrm{L}^{-1}, \mathrm{COD}=875.0 \mathrm{mg} \mathrm{L}^{-1}$, and SS $=432.8 \mathrm{mg} \mathrm{L}^{-1}$. The fluctuations around these averages, evidenced by the standard deviation (SD) and range min-max, were, on the whole, noticeable considering that all the individual data referred to average daily samples. Indeed, these statistical findings were typical of all small communities [14], but in this specific case they were, to a certain extent, influenced by the short sewerage network (only about $300 \mathrm{~m}$ ), which cannot exert a significant levelling action on the flowrate and peaks of quality. The concentrations of FIs were, on the whole, aligned with references in the scientific literature, as already reported in the introduction $[18,24,25]$. The average concentration of FC amounted to $9.003 \times 10^{6} \mathrm{UFC} \cdot 100 \mathrm{~mL}^{-1}$ and the concentration of EN was $2.413 \times 10^{6} \mathrm{UFC} \cdot 100 \mathrm{~mL}^{-1}$, almost an order of magnitude lower.

The average temperature of the raw sewage was $22.4^{\circ} \mathrm{C}$, with a short excursion in the range $20.2-24.8^{\circ} \mathrm{C}$ during the whole experimentation period. 


\subsection{Plant Performances}

Figure 2 shows the statistical data of $\mathrm{BOD}_{5}, \mathrm{COD}$, and $\mathrm{SS}$ at the three control points along the treatment plant. These values are displayed as mean, standard deviation (SD), and range min-max.

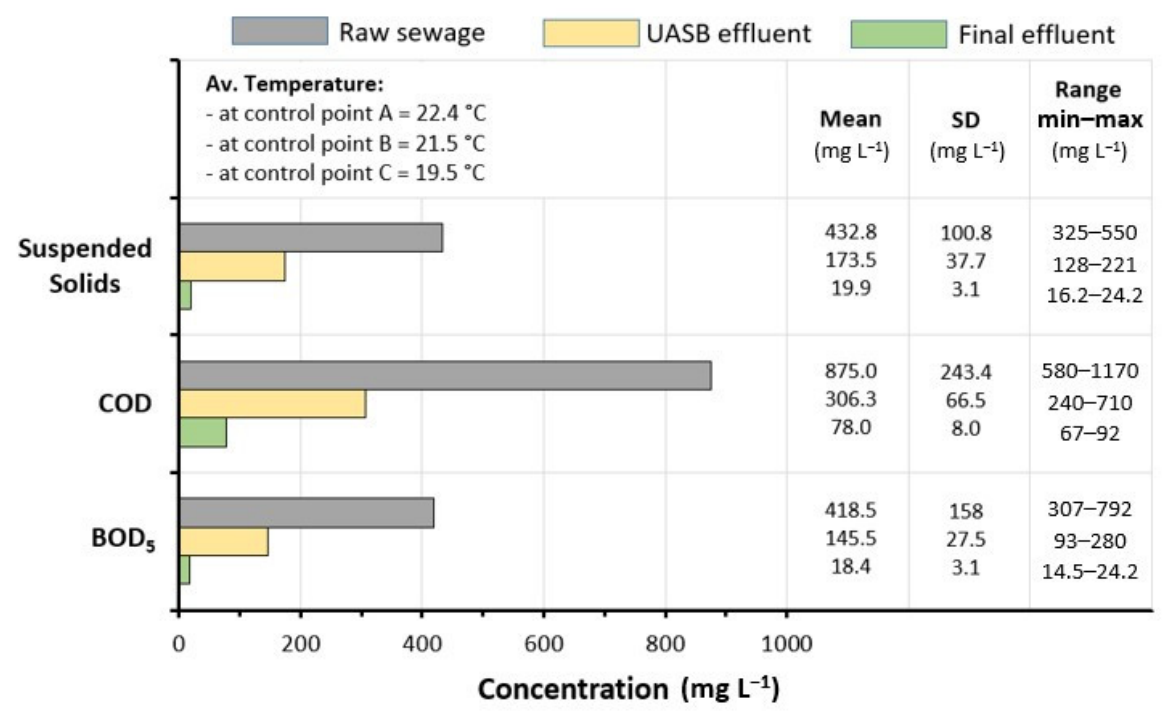

Figure 2. Statistical values of $\mathrm{BOD}_{5}, \mathrm{COD}$, and $\mathrm{SS}$ in the three control points along the treatment plant (values are represented as mean, standard deviation, and range min-max).

The data in Figure 2 show, first of all, a good physical-chemical quality of the final effluent, as attested by the average values of $\mathrm{BOD}_{5}=18.4 \mathrm{mg} \mathrm{L}^{-1}, \mathrm{COD}=78.0 \mathrm{mg} \mathrm{L}^{-1}$, and $\mathrm{SS}=19.9 \mathrm{mg} \mathrm{L}^{-1}$. The related average treatment efficiency of the whole plant amounted, respectively, to $95.6 \%, 91.0 \%$, and $95.4 \%$. In particular, the important contribution of the UASB to the $\mathrm{BOD}_{5}$ removal efficiency stands out, with an average value of $65.2 \%$ (compared to average $30 \%$ (range $20-40 \%$ ), which is expected from a normal primary sedimentation $[13,55]$. This demonstrates the effectiveness of the UASB reactor in the anaerobic biological degradation of the organic substrate, in this case well favored by the high temperature of the raw sewage. The removal efficiency of SS in this unit amounted to $59.9 \%$, quite comparable to that of a normal primary sedimentation [13]. Very similar yield has been found on other UASBs in sewage pre-treatments [24] Also, the relatively small value of SS in the final effluent (average SS $=19.9 \mathrm{mg} \mathrm{L}^{-1}$ ) was noticeable. It is very likely that the effective filtration-sedimentation action (in addition to biodegradation) exerted by the SSHFP system was decisive for this result. Obviously, this action also improved the final values of $\mathrm{BOD}_{5}$ and $\mathrm{COD}$.

Figure 3 shows the concentrations of FC and EN at the three control points. In this case, a logarithmic scale was used to facilitate the reading of data. The whole plant demonstrated the ability to reduce the concentration of these two indicators to average concentrations of $162 \cdot 10^{3}$ UFC $100 \mathrm{~mL}^{-1}$ and $96 \cdot 10^{3}$ UFC $100 \mathrm{~mL}^{-1}$, respectively. The overall average removal efficiency results of $98.2 \%$ (1.74 log removal) for FC and $96.0 \%$ (1.40 log removal) for EN. 


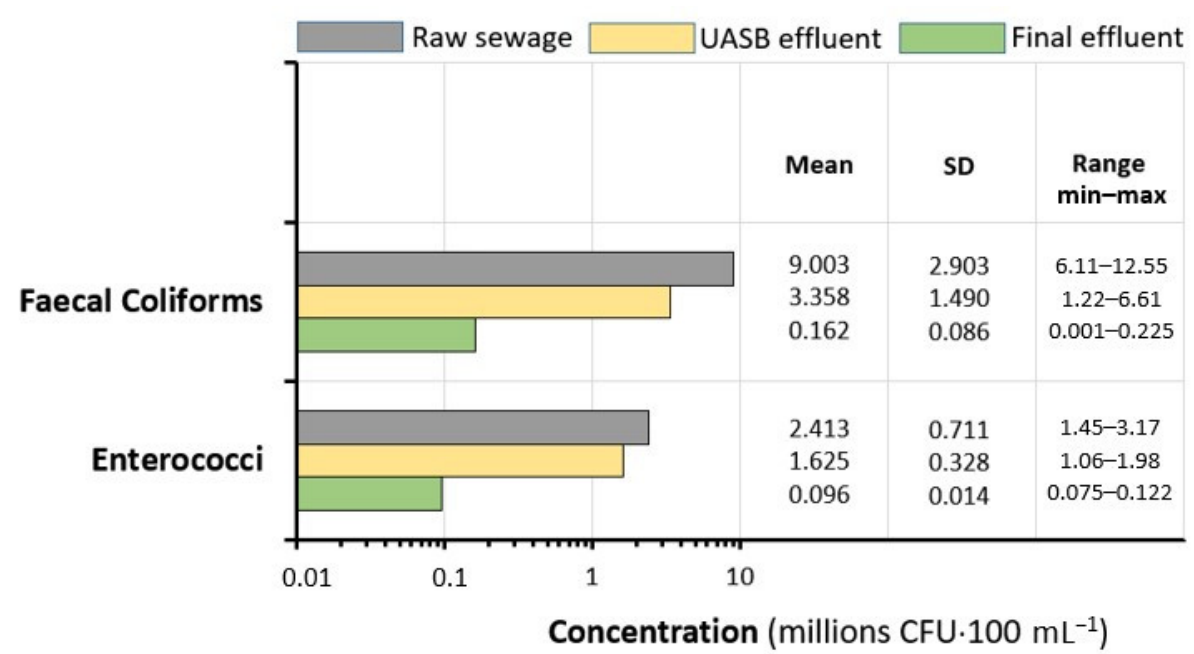

Figure 3. Statistical values of FC and EN concentration (on a logarithmic scale) at the three control points along the treatment plant (values are represented as mean, standard deviation, and range $\min -\max )$.

The share of the individual units, UASB and SSHFP, in these overall performances is well represented in Figure 4 (for FC) and Figure 5 (for EN), where the individual dots refer to the 60 consecutive samples collected at the three control points.

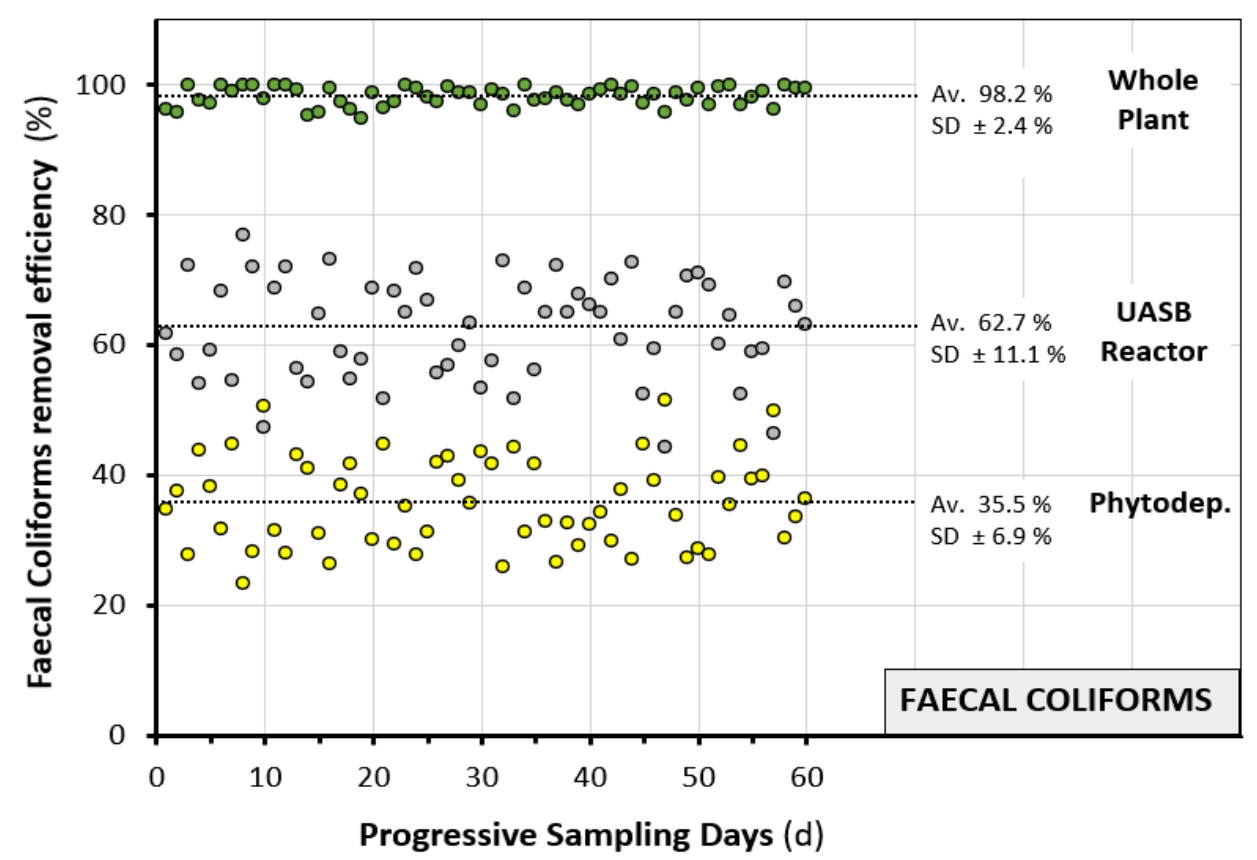

Figure 4. Overall removal efficiency of FC (green dots) and relative share given by UASB (gray dots) and SSHFP (yellow dots), as a function of the progressive days of sampling. 


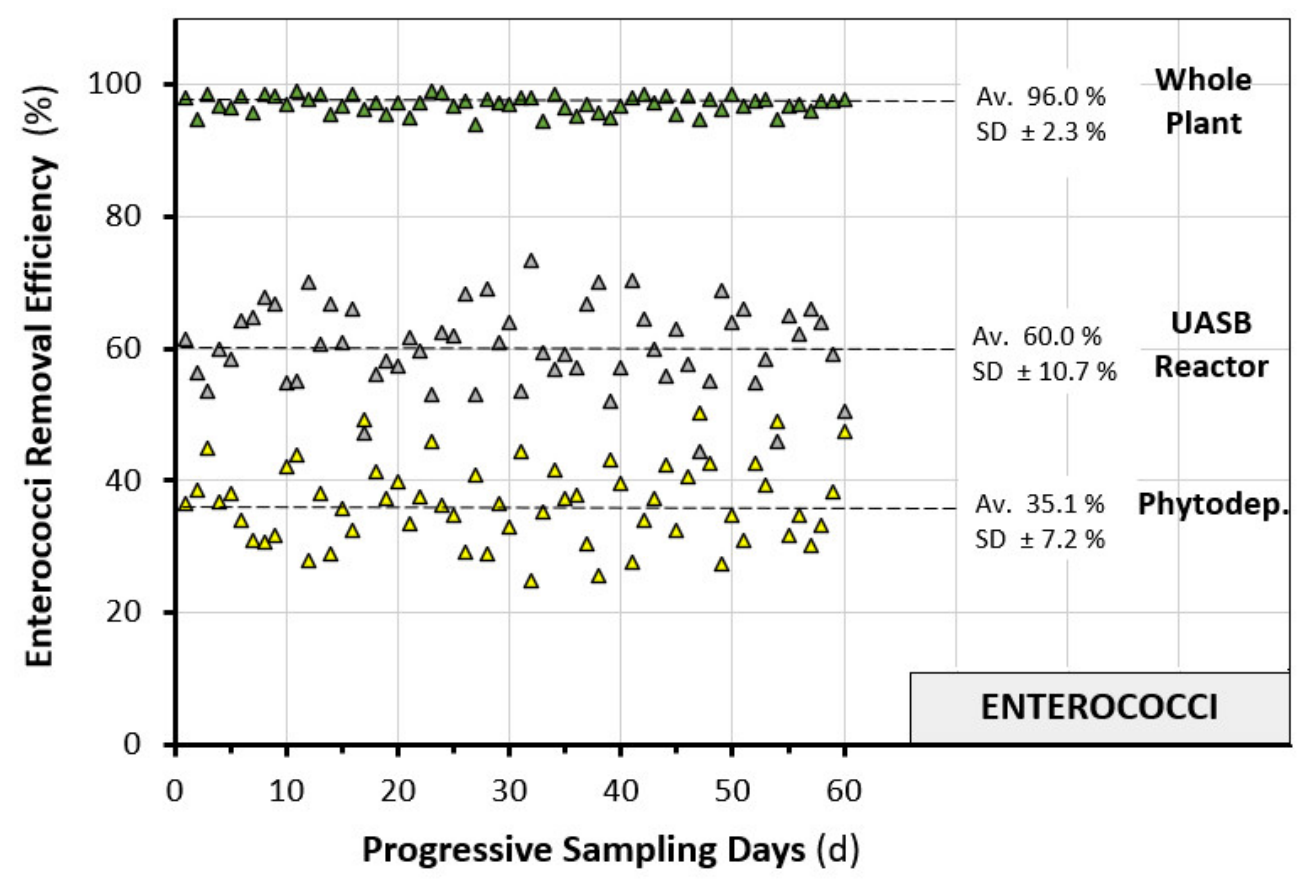

Figure 5. Overall removal efficiency of EN (green dots) and relative share given by UASB (gray dots) and SSHFP (yellow dots), as a function of the progressive days of sampling.

The two graphs highlight the following:

UASB pre-treatment contributed to the removal of both FIs (on average $62.7 \%$ for FC and $60.0 \%$ for EN). As a comparison, in a common primary treatment TC and FC are removed at a rate of approximately $50 \%$ (range $40-60 \%$ ) [13,17]. This efficiency is commonly just below that of SS, which ranges around $60 \%$ (range $55-70 \%$ ) [13-55]. The increased efficiency achieved for the two FIs, in this specific experimentation, could be ascribed to their mortality, which was, in turn, related to the high retention time in the reactor $(13.5 \mathrm{~h})$ and to the intense biological activity. The contribution of mortality to the removal of FIs can be roughly estimated in the order of $10-15 \%$.

The phytodepuration stage, although to a lesser extent than the UASB stage, contributed to the overall efficiency of FIs removal (on average: 35.5\% for FC and 35.1\% for EN), but above all it exerted a remarkable finishing treatment of the various physical-chemical and microbiological pollution parameters. The efficiency of phytodepuration is affected by different factors, among which the most important are the type of process and the specific hydraulic load $\left(\mathrm{m}^{3} \mathrm{~d}^{-1} \mathrm{~m}^{-2}\right)$, or more simply the HRT. A survey on 60 phytodepuration plants with emergent vegetation around the world highlighted that HRT values of 2.0, 3.0, 5.5, and 7.0 days resulted in respective FC removal efficiency of $76.2 \%, 79.4 \%, 92.1 \%$, and $95.3 \%$ [35]. The same survey [35] revealed that removal of TC and FC is usually 95 to $>99 \%$, while removal of EN is lower, usually $80-95 \%$. The best removal efficiencies are achieved by plants with primary treatment procedures. Regarding the type of process, the same survey [35] highlighted the higher efficiency of SSHFP (av. FC removal 91.5\%), compared to the more traditional SHFP (av. FC removal 85.4\%), while absolute hybrid systems would be preferred (FC removal, up to $99.4 \%$ ) [35,38,56-58]. However, it seems correct to observe that there are many complex factors capable of influencing the goodness and sustainability of a single process, as well as of a whole plant. Among them, there is certainly the exposure of the population to health risks. In fact, the investigated plant was fully covered and this brought important health benefits to the local population. In particular, there were no significant odor emissions and no proliferation of insects and other disease vectors, due to the absence of stagnant or semi-stagnant water. This last aspect is of relevant importance for all tropical areas, which are periodically subject to 
outbreaks of "dengue", a hemorrhagic fever caused by the dengue virus spread by the Aedes mosquitoes (mainly Aedes aegypti) that breed just on the surface of stagnant water.

It can be noted that the average removal efficiency of EN is systematically, albeit slightly, lower than that of FC. This finding confirms the greater resilience of EN, as was already highlighted in a few previous studies [10]. In effect, only E. coli, among the members of the FC community, has demonstrate a comparable environmental persistence and sometimes even greater [2]. The strong persistence of these two specific FIs was also proved with regards to several antibiotics in hospital wastewaters [11].

\subsection{Comparison among Removal Efficiency of FIs with $S S$ and $B O D_{5}$}

The removal of FIs within the treatment plant is determined partly by the removal of SS (as members of bacteria microcosm, FC and EN are part of SS) and partly by their progressive mortality. The latter is strongly linked to the biological activity, which is also responsible for $\mathrm{BOD}_{5}$ removal. In effect, inside the wide microbiological community many mortality mechanisms are active, such as protozoa predation, the lytic action of certain bacteria, and the adverse effects of the physical-chemical environment (temperature, dissolved oxygen, substrates, $\mathrm{pH}$, salinity, $\mathrm{rH}$, sunlight, toxins). It is also worth highlighting the sorption action of biological flocs (granular flocs in UASB, bacteria aggregations in SSHFP). The two FI removal phenomena are present in both stages UASB and SSHFP. Theoretically, the greatest removal of the two FIs by sedimentation is expected in the UASB stage, while their greatest removal by mortality is expected in phytodepuration. It may therefore be interesting to investigate the potential level of equivalence between the removal efficiencies of the two FIs with the removal efficiency of SS and $\mathrm{BOD}_{5}$. The analysis of this equivalence could give indications of the relevance of each removal phenomena (mechanical or biological mortality). In relation to the UASB pre-treatment, Figure 6 shows the values of the removal efficiency of the two FIs as a function of the removal efficiency of SS. The graph also reports the equivalence line, along which the removal efficiency of the FIs and SS would be identical. It can be seen that the various points are distributed fairly close to the equivalence line, suggesting that the removal efficiency of FIs in this stage matches the removal efficiency of SS quite well. More detailed analysis of the distribution leads to the following:

- Average FC removal efficiency $=62.7 \%$.

- Average EN removal efficiency $=60.0 \%$.

- Average SS removal efficiency $=59.9 \%$.

- Average deviation of FC removal efficiency from the equivalence line $=4.11 \%$.

- Average deviation of EN removal efficiency from the equivalence line $=0.83 \%$.

The deviation $\mathrm{D}$ at any specific $\mathrm{x}$-axis value (removal efficiency of SS, in this specific case) is calculated as the difference between the y-axis value (removal efficiency of any FI in this specific case) and the corresponding value on the equivalence line. There is, therefore, a good level of equivalence between the two FIs and SS, although from a scientific point of view this is not easy to prove. In fact, various phenomena within the UASB reactor contribute to the removal of both SS and FI, including the following: sedimentation, filtration by the granular biological bed, biological degradation (which is active in the destruction of VSS and also affects the mortality of FIs).

Figure 7 shows the level of equivalence between the two FIs and $\mathrm{BOD}_{5}$, again with reference to the UASB reactor alone. Even in this case, there was a good level of equivalence, given that the above cited phenomena affected both the removal of $\mathrm{BOD}_{5}$ and the removal of FIs. The statistical analysis of dispersion led to the following results:

- Average FC removal efficiency $=62.7 \%$.

- Average EN removal efficiency $=60.0 \%$.

- Average $\mathrm{BOD}_{5}$ removal efficiency $=65.2 \%$.

- Average deviation of FC removal efficiency from the equivalence line $=-4.66 \%$.

- Average deviation of EN removal efficiency from the equivalence line $=-8.08 \%$. 


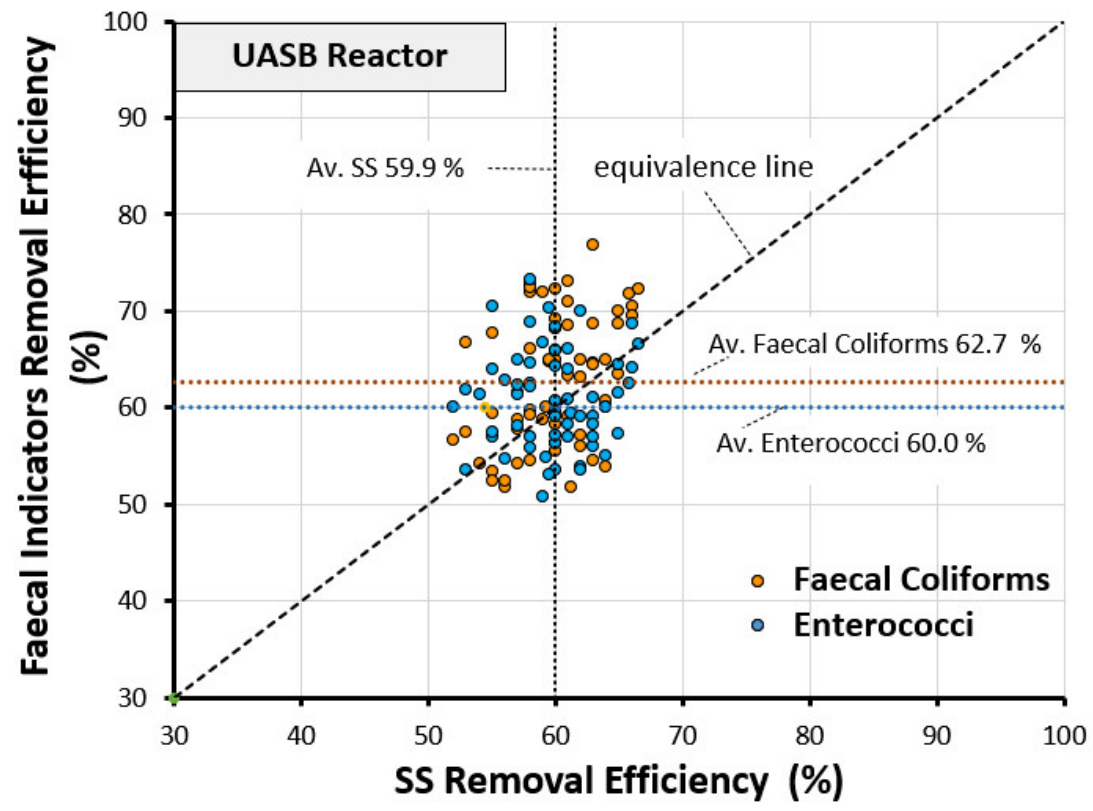

Figure 6. Removal efficiency of FIs against removal efficiency of SS, with regard to the UASB reactor.

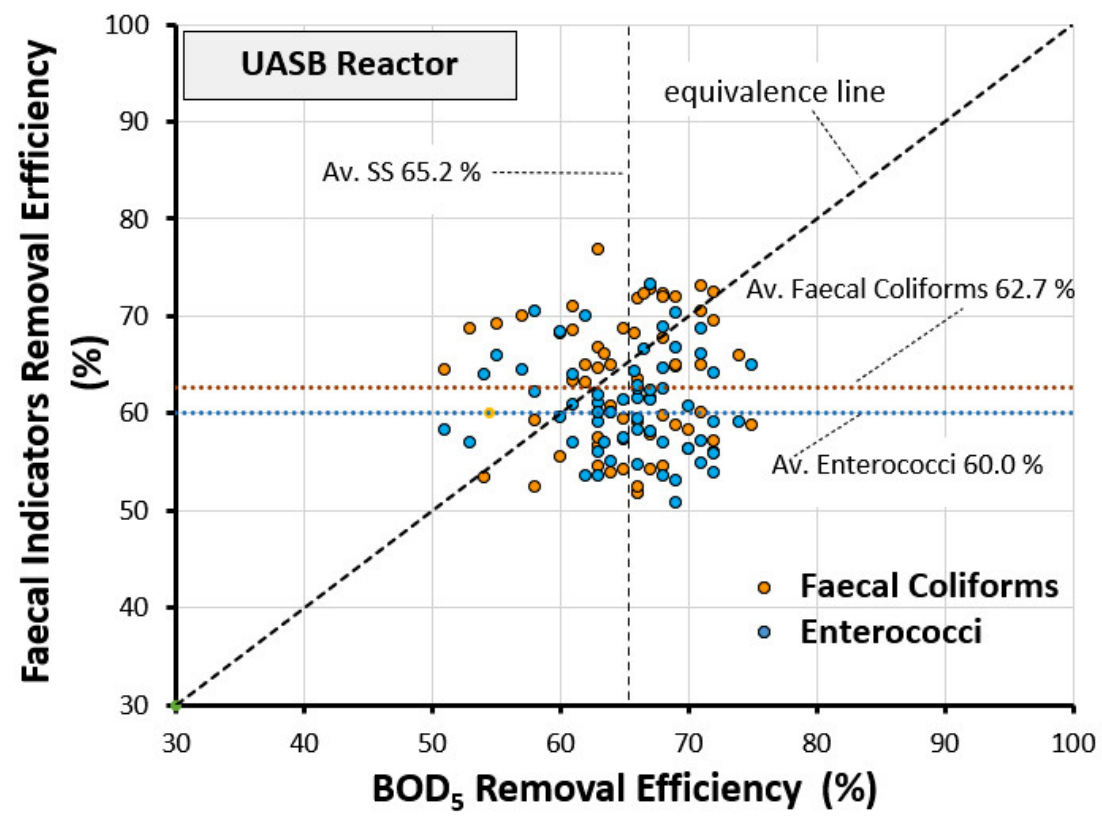

Figure 7. Removal efficiency of FIs against removal efficiency of BOD5, with regard to UASB reactor.

The minus sign of the deviation values simply indicates that the average values of FIs are below the equivalence line.

Figures 8 and 9 show a similar representation for the overall plant. In this case, the mean values of the FIs removal efficiency are markedly above the equivalence line. In the graph of Figure 8 (equivalence to SS), the average deviation from the equivalence line is $2.8 \%$ for $\mathrm{FC}$ and $1.7 \%$ for EN and in the graph of Figure 9 (equivalence to $\mathrm{BOD}_{5}$ ) it is $1.6 \%$ for FC and $0.6 \%$ for EN. The removal mechanisms for the two FIs are the same of those described above. Thus, a good level of equivalence was also achieved between the removal performance of FIs and the removal performance of $\mathrm{SS}$ and $\mathrm{BOD}_{5}$. The greater yield of FIs compared to $\mathrm{SS}$ and $\mathrm{BOD}_{5}$ was likely due to the continuous decay of the two indicators, due to the extended retention time in SSHFP, while SS and $\mathrm{BOD}_{5}$ were very close to a stabilization level. 


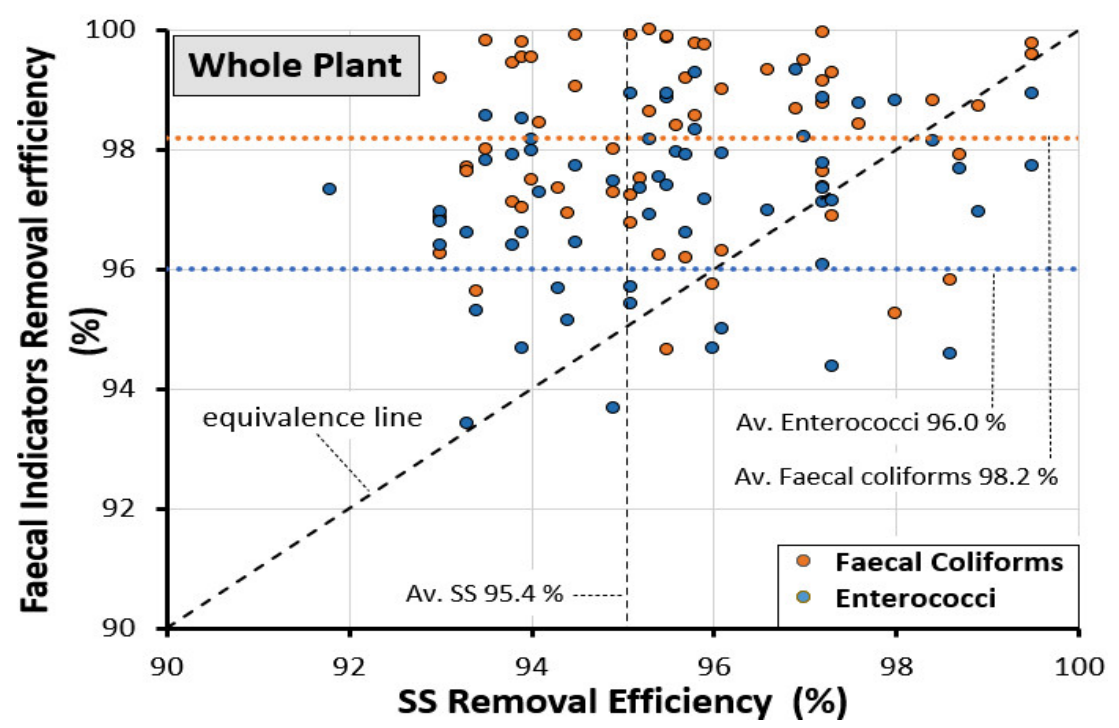

Figure 8. Removal efficiency of FIs against removal efficiency of SS, with regard to whole plant.

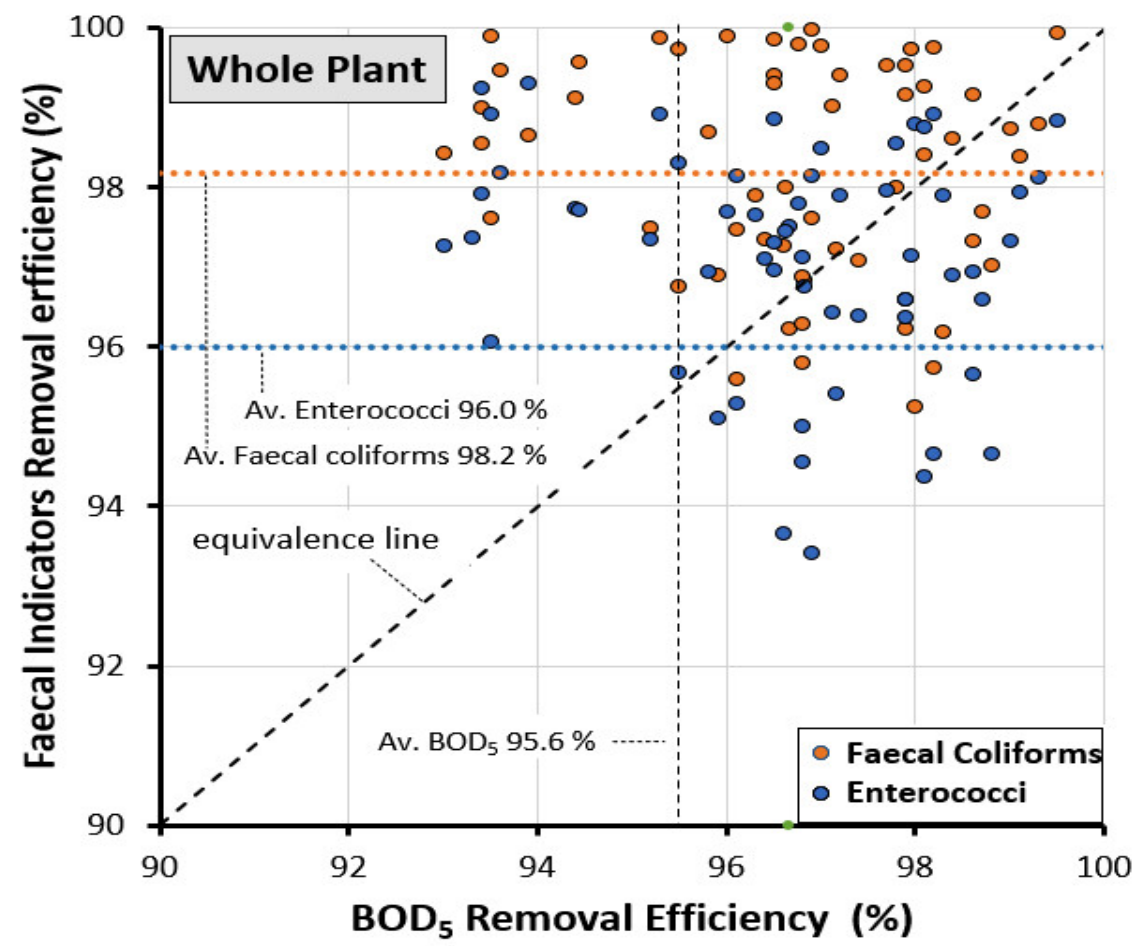

Figure 9. Removal efficiency of FIs against removal efficiency of $\mathrm{BOD}_{5}$ with reference to the whole plant.

\subsection{Correlation between the Concentrations of EN and FC}

It is interesting to highlight the correlation between the concentrations of EN and FC. This correlation is shown in a double-logarithmic diagram in Figures 10 and 11. In particular, Figure 10 refers to sampling points A (raw sewage) and B (UASB effluent), while Figure 11 refers to sampling point $C$ (final effluent). For the three dispersions, the relative linear regression lines were elaborated with the respective equations and their coefficients of determination $\mathrm{R}^{2}$. As known, $\mathrm{R}^{2}$ is a statistical measure of how close the dispersed data are to the regression line. In other words, this coefficient assesses how strong the linear relationship is between the two variables under consideration, specifically the two indicators FC and EN. $\mathrm{R}^{2}$ ranges between 0.0 and 1.0 and a value of 1.0 indicates a perfect 
reliable equation for future forecasts, while a value of 0.0 indicates that the equation fails to represent the data at all.

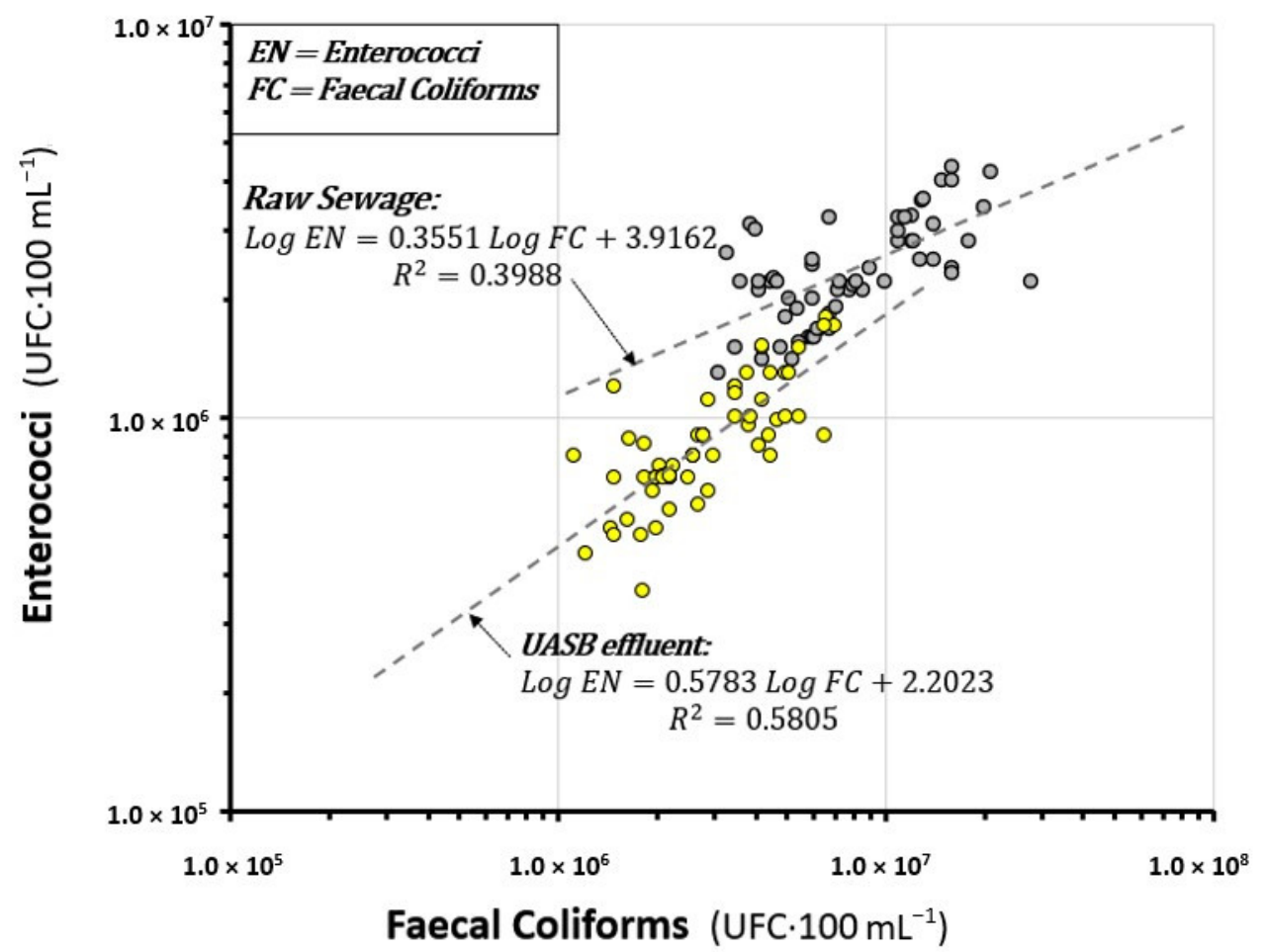

Figure 10. EN concentration against FC concentration (on logarithmic scales) for raw sewage (green dot) and UASB effluent (yellow dot).

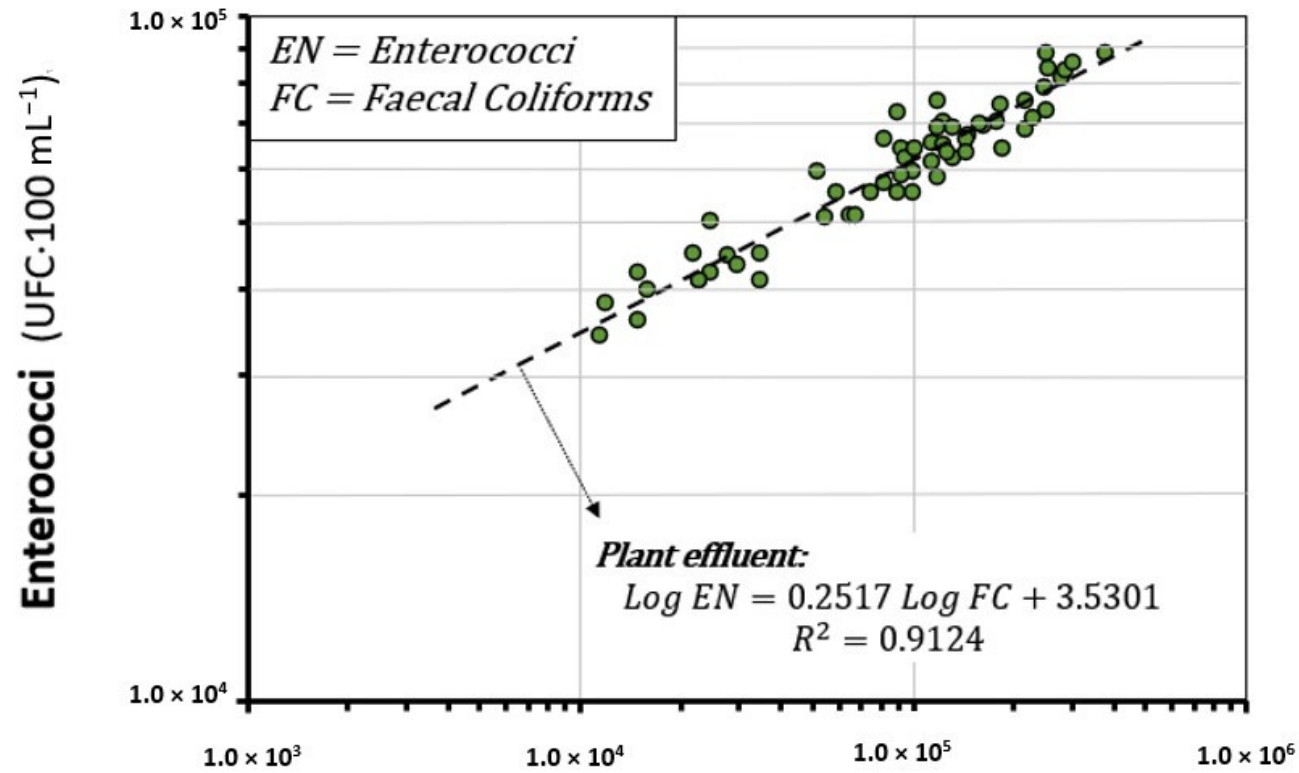

Faecal Coliforms (UFC. $100 \mathrm{~mL}^{-1}$ )

Figure 11. EN concentration against FC concentration for plant effluent (on logarithmic scales).

It can be observed that in Figure 10 the level of dispersion of the data for control points A and B (raw sewage and UASB effluent respectively) is so wide that the coefficients of determination are rather low and, therefore, the relative mathematical correlations between the two FIs are not sufficiently reliable. In particular $\mathrm{R}^{2}=0.3988$ (raw sewage) 
and $R^{2}=0.5805$ (UASB effluent) suggest that only, respectively, about $40 \%$ and $58 \%$ of the EN concentration could be predicted by the knowledge of FC concentration. On the other hand, in the case of Figure 11 (final effluent) the dispersion of the data is decidedly rather reduced, such as to determine a coefficient of determination $R^{2}=0.9124$, which makes the mathematical correlation $\log E N=0.2571 \log F C+3.5301$ quite reliable. This means that the homogeneity and quality of the final effluent allows researchers to calculate, with good reliability, the concentration of the more specific indicator EN from the simple analysis of FC and vice versa. In other words, it would be sufficiently valid to carry out the analytical determination of a single FI on the treated effluent.

\section{Conclusions}

The investigated plant, based on a UASB reactor followed by a sub-surface horizontal flow phytodepuration (SSHFP) system, proved particularly valuable for the treatment of sewage in a small rural community of 1650 inhabitants. Along the six-month trial, the plant achieved a mean removal efficiency of $98.2 \%$ (1.74 log removal) for fecal coliforms (FC) and $96.0 \%$ (1.40 log removal) for Enterococci (EN), as well as of $95.6 \%$ for $\mathrm{BOD}_{5}, 91.0 \%$ for COD, and $95.4 \%$ for SS. The contribution of the UASB reactor to this overall performance proved to be very significant as it alone achieved a $62.7 \%$ yield for FC and $60.0 \%$ for EN, as well as $65.2 \%$ for $\mathrm{BOD}_{5}$ and $65.0 \%$ for $\mathrm{SS}$.

EN were chosen (in addition to FC) as highly specific fecal indicator (FI)s, suitable for this particular case, due to their high environmental persistence and the consequent increased risk to human health. In fact, the experimental results confirmed their lower removal efficiency compared to FC, albeit to a rather limited extent $(2.7 \%$ lower on the overall plant). The mechanisms leading to such a high performance in the removal of the two FIs are mechanical and biological, and both are present in the UASB phase and in the subsequent phytodepuration phase. The former consists mainly of filtration and sedimentation, while the latter is related to microorganism decay due to protozoa predation, the lytic action of certain bacteria, and the adverse effects of the physical-chemical environment (temperature, dissolved oxygen, substrates, $\mathrm{pH}$, salinity, $\mathrm{rH}$, sunlight, toxins). It is also worth highlighting the sorption action of biological flocs (granular flocs in UASB, bacteria aggregations in the porous media of phytodepuration). As a consequence of these phenomena, the removal efficiencies of the two FIs were found to be well equivalent to the removal efficiencies of $\mathrm{SS}$ and $\mathrm{BOD}_{5}$, for both the whole plant and UASB reactor alone.

The research demonstrated the close correlation between the concentrations of EN and FC in the final effluent of the plant. This correlation can be explained by the following mathematical expression of the regression line $\log E N=0.2571 \log F C+3.5301$ with a coefficient of determination $R^{2}=0.912$. This means that the homogeneity and quality of the final effluent allows researchers to calculate, with good reliability, the concentration of the more specific indicator EN from the simple analysis of FC and vice versa. On the other hand, the level of dispersion of data for raw sewage and UASB effluent was so great that it led to a rather low coefficient of determination $\left(R^{2}=0.3988\right.$ for raw sewage and $R^{2}=0.5805$ for UASB effluent), making the similar mathematical correlations not adequately reliable.

The investigated plant brought important health benefits to the local population. In particular, there were no significant odor emissions and no proliferation of insects and other disease vectors, due to the absence of stagnant or semi-stagnant water. This last aspect is of relevant importance for all tropical areas, which are periodically subject to outbreaks of "dengue", a hemorrhagic fever caused by the dengue virus spread by Aedes mosquitoes (mainly Aedes aegypti) that breed just on the surface of stagnant water.

A course porous medium (50-100 mm) was applied in the SSHFP in order to ensure long hydraulic retention times, avoiding a high risk of clogging. However, the removal efficiency of SS (and of all other parameters analyzed) was very good without significant head losses. This result needs to be confirmed in longer experimentation periods, but, at the same time, it encourages the experimentation of a finer porous medium $(10-20 \mathrm{~mm})$, placed in the terminal zone of the phytodepuration unit, in order to obtain further improvements 
of the treatment efficiency. The results presented here are from the first phase of an experimentation process that will continue for a longer period, in order to achieve a higher level of reliability of the research findings. The possibility of recovering the biogas produced should be a further interesting chapter for future research.

Author Contributions: Conceptualization: M.R., P.V. and E.C.R.; methodology: M.R., E.C.R., P.V. and F.C.; validation: M.R., P.V., E.C.R. and F.C.; investigation: M.R., P.V. and E.C.R.; writing-original draft preparation: M.R. and P.V.; writing-review and editing: M.R. and E.C.R. All authors have read and agreed to the published version of the manuscript.

Funding: This research did not receive external funding.

Informed Consent Statement: Not applicable.

Conflicts of Interest: The authors declare no conflict of interest.

\section{References}

1. Spence, S.D. Microorganisms-The Coliform Group Bacteria. Available online: https://www.scribd.com/presentation/42505500 0/microorg-3-ppt (accessed on 17 January 2021).

2. WHO. Indicators of microbial water quality. In Water Quality: Guidelines, Standards and Health. Assessment of Risk and Risk Management for Water-Related Infectious Disease; Fewtrell, L., Bartram, J., Eds.; World Health Organization by IWA Publishing: London, UK, 2001; p. 424.

3. Janahi, E.M.; Mustafa, S.; Parkar, S.F.D.; Naser, H.A.; Eisa, Z.M. Detection of Enteric Viruses and Bacterial Indicators in a Sewage Treatment Center and Shallow Water Bay. Int. J. Environ. Res. Public Health 2020, 17, 6483. [CrossRef]

4. Solo-Gabriele, H.M.; Wolfert, M.A.; Desmarais, T.R.; Palmer, C.J. Sources of Escherichia coli in a coastal subtropical environment. Appl. Environ. Microbiol. 2000, 66, 230-237. [CrossRef]

5. Yuan, T.; Vadde, K.K.; Tonkin, J.D.; Wang, J.; Lu, J.; Zhang, Z.; Zhang, Y.; McCarthy, A.J.; Sekar, R. Urbanization Impacts the Physicochemical Characteristics and Abundance of Fecal Markers and Bacterial Pathogens in Surface Water. Int. J. Environ. Res. Public Health 2019, 16, 1739. [CrossRef]

6. Mahmud, Z.H.; Islam, M.S.; Imran, K.M.; Hakim, S.A.I.; Worth, M.; Ahmed, A.; Hossan, S.; Haider, M.; Islam, M.R.; Hossain, F.; et al. Occurrence of Escherichia coli and faecal coliforms in drinking water at source and household point-of-use in Rohingya camps, Bangladesh. Gut Pathog. 2019, 11, 52. [CrossRef]

7. Qin, G.; Liu, J.; Xu, S.; Sun, Y. Pollution Source Apportionment and Water Quality Risk Evaluation of a Drinking Water Reservoir during Flood Seasons. Int. J. Environ. Res. Public Health 2021, 18, 1873. [CrossRef] [PubMed]

8. Afolabi, E.; Quilliam, R.S.; Oliver, D.M. Impact of Freeze-Thaw Cycles on Die-Off of E. coli and Intestinal Enterococci in Deer and Dairy Faeces: Implications for Landscape Contamination of Watercourses. Int. J. Environ. Res. Public Health 2020, 17, 6999. [CrossRef] [PubMed]

9. Ludwig, W.; Schleifer, K.; Whitman, W.B. Family IV. Enterococcaceae fam. nov. In Bergey's Manual of Systematic Bacteriology, 2nd ed.; De Vos, P., Garrity, G.M., Jones, D., Krieg, N.R., Ludwig, W., Rainey, F.A., Schleifer, K.H., Whitman, W.B., Eds.; Springer: New York, NY, USA, 2009; Volume 3, p. 594.

10. Lebreton, F.; Willems, R.J.L.; Gilmore, M.S. Enterococcus Diversity, Origins in Nature, and Gut Colonization. In Enterococci: From Commensals to Leading Causes of Drug Resistant Infection; Gilmore, M.S., Clewell, D.B., Ike, Y., Shankar, N., Eds.; Massachusetts Eye and Ear Infirmary: Boston, MA, USA, 2014. Available online: https:/ /www.ncbi.nlm.nih.gov/books/NBK190427/ (accessed on 16 January 2021).

11. Thamlikitkul, V.; Tiengrim, S.; Thamthaweechok, N.; Buranapakdee, P.; Chiemchaisri, W. Contamination by Antibiotic-Resistant Bacteria in Selected Environments in Thailand. Int. J. Environ. Res. Public Health 2019, 16, 3753. [CrossRef]

12. Gotkowska-Płachta, A. The Prevalence of Virulent and Multidrug-Resistant Enterococci in River Water and in Treated and Untreated Municipal and Hospital Wastewater. Int. J. Environ. Res. Public Health 2021, 18, 563. [CrossRef]

13. Tchobanoglous, G.; Burton, F.L.; Stensel, H.D.; Metcalf, E. Wastewater Engineering: Treatment and Reuse; McGraw-Hill: New York, NY, USA, 2003.

14. Capodaglio, A.G.; Hlavínek, P.; Raboni, M. Advances in wastewater nitrogen removal by biological processes: State of the art review. Rev. Ambiente Água 2013, 11, 250-267. [CrossRef]

15. Capodaglio, A.G.; Hlavínek, P.; Raboni, M. Physico-chemical technologies for nitrogen removal from wastewaters: A review. Rev. Ambiente Água 2015, 10, 481-498.

16. Copelli, S.; Raboni, M.; Urbini, G. Water pollution: Biological oxidation and natural control techniques. In Reference Module in Chemistry, Molecular Sciences and Chemical Engineering; Reedijk, J., Ed.; Elsevier: Amsterdam, The Netherlands, 2015; pp. 1-28.

17. George, I.; Crop, P.; Servais, P. Fecal coliform removal in wastewater treatment plants studied by plate counts and enzymatic methods. Water Res. 2002, 36, 2607-2617. [CrossRef]

18. Raboni, M.; Gavasci, R.; Torretta, V. Assessment of the Fate of Escherichia coli in Different Stages of Wastewater Treatment Plants. Water Air Soil Pollut. 2016, 227, 455. [CrossRef] 
19. APAT-IRSA CNR. Metodi per la Determinazione di Microorganismi Indicatori Di Inquinamento e di Patogeni. Metod. Anal. Acque 2003, 3, 865 .

20. Cavallini, G.S.; De Campos, S.X.; De Souza, J.B.; De Souza Vidal, C.M. Evaluation of the Physical-Chemical Characteristics of Wastewater After Disinfection with Peracetic Acid. Water Air Soil Pollut. 2013, 224, 1752. [CrossRef]

21. Raboni, M.; Gavasci, R.; Urbini, G. UASB followed by Sub-Surface Horizontal Flow Phytodepuration for the Treatment of the Sewage Generated by a Small Rural Community. Sustainability 2014, 6, 6998-7012. [CrossRef]

22. Koivunen, J.; Sitonen, A.; Heinonen-Tanskia, H. Elimination of enteric bacteria in biological-chemical wastewater treatment and tertiary filtration units. Water Res. 2003, 37, 690-698. [CrossRef]

23. Boni, M.R.; Copelli, S.; Raboni, M. Study of the performance of disinfection with sodium hypochlorite on a full-scale sewage treatment plant. Rev. Ambiente Água 2020, 15, e2652.

24. Landa-Cansigno, O.; Durán-Álvarez, J.C.; Jiménez-Cisneros, B. Retention of Escherichia coli, Giardia lamblia cysts and Ascaris lumbricoides eggs in agricultural soils irrigated by untreated wastewater. J. Environ. Manag. 2013, 128, 22-29. [CrossRef] [PubMed]

25. Barrios-Hernandez, M.L.; Pronk, M.K.; Garcia, H.; Boersma, A.; Brdjanovic, D.; van Loosdrecht, M.C.M.; Hooijmans, C.M. Removal of bacterial and viral indicator organisms in full-scale aerobic granular sludge and conventional activated sludge systems. Water Res. 2020, 6, 100040. [CrossRef] [PubMed]

26. Vilanova, X.; Manero, A.; Cerda-Cuellar, M.; Blanch, A.R. The composition and persistence of FC and enterococcal populations in sewage treatment plants. J. Appl. Microbiol. 2004, 96, 279-288. [CrossRef] [PubMed]

27. Dias, S.; Mucha, A.P.; Crespo, R.D.; Rodrigues, P.; Almeida, C.M.R. Livestock Wastewater Treatment in Constructed Wetlands for Agriculture Reuse. J. Environ. Res. Public Health 2020, 17, 8592. [CrossRef]

28. Nawaz, N.; Ali, S.; Shabir, G.; Rizwan, M.; Shakoor, M.B.; Shahid, M.J.; Afzal, M.; Arslan, M.; Hashem, A.; Abd_Allah, E.F.; et al Bacterial Augmented Floating Treatment Wetlands for Efficient Treatment of Synthetic Textile Dye Wastewater. Sustainability 2020, 12, 3731. [CrossRef]

29. Raboni, M.; Torretta, V.; Viotti, P.; Urbini, G. Experimental plant for the physical-chemical treatment of groundwater polluted by Municipal Solid Waste (MSW) leachate, with ammonia recovery. Rev. Ambiente Água 2013, 8, $22-32$.

30. Trulli, E.; Torretta, V.; Rada, E.C. Water Restoration of an Urbanized Karst Stream by Free-Water-Surface Conducted Wetlands as Municipal Wastewater Posttreatment. UPB Sci. Bull 2016, 78, 163-174.

31. Reinoso, R.; Torres, L.A.; Bécares, E. Efficiency of natural systems for removal of bacteria and pathogenic parasites from wastewater. Sci. Total Environ. 2008, 395, 80-86. [CrossRef]

32. Pant, A.; Mittal, A.K. Monitoring of pathogenicity of effluents from the UASB based sewage treatment plant. Environ. Monit. Assess. 2007, 133, 43-51. [CrossRef]

33. Tessele, F.; Monteggia, L.O.; Rubio, J. Treatment of municipal wastewater UASB reactor effluent by unconventional flotation and uv disinfection. Water Sci. Technol. 2005, 52, 315-322. [CrossRef]

34. Antunes, S.; Dionisio, L.; Silva, M.C.; Valente, M.S.; Borrego, J.J. Coliforms as Indicators of Efficiency of Wastewater Treatment Plants. In Proceedings of the 3rd International Conference on Energy, Environment, Ecosystems and Sustainable Development, IASME/WSEAS, Agios Nikolaos, Greece, 24-26 July 2007; pp. 26-29.

35. Vymazal, J. Removal of Enteric Bacteria in Constructed Treatment Wetlands with Emergent Macrophytes: A Review. J. Environ. Sci. Health 2005, 40, 1355-1367. [CrossRef] [PubMed]

36. Rahman, M.E.; Halmi, M.I.E.B.; Samad, M.Y.B.A.; Uddin, M.K.; Mahmud, K.; Shukor, M.Y.A.; Abdullah, S.R.S.; Shamsuzzaman, S.M. Design, Operation and Optimization of Constructed Wetland for Removal of Pollutant. Int. J. Environ. Res. Public Health 2020, 17, 8339. [CrossRef]

37. De La Mora-Orozco, C.; Gonzales-Acuna, I.J.; Saucedo-Teran, R.A.; Flores-Lopez, H.E.; Rubio-Arias, H.O.; Ochoa_riviero, J.M. Removing Organic Matter and Nutrients from Pig Farm Wastewater with a Constructed Wetland System. Int. J. Environ. Res. Public Health 2018, 15, 1031. [CrossRef]

38. Herrera-Meliàn, J.A. Sustainable Wastewater Treatment Systems (2018-2019). Sustainability 2020, 12, 1940. [CrossRef]

39. Raboni, M.; Torretta, V.; Urbini, G. Influence of strong diurnal variations in sewage quality on the performance of biological denitrification in small community wastewater treatment plants (WWTPs). Sustainability 2013, 5, 3679-3689. [CrossRef]

40. Raboni, M.; Torretta, V.; Viotti, P.; Urbini, G. Pilot experimentation with complete mixing anoxic reactors to improve sewage denitrification in treatment plants in small communities. Sustainability 2014, 6, 112-122. [CrossRef]

41. Sandoval-Herazo, L.C.; Alvarado-Lassman, A.; Marin-Muniz, J.L.; Mendez-Contreras, J.M.; Zamora-Castro, S.A. Effects of the Use of Ornamental Plants and Different Substrates in the Removal of Wastewater Pollutants through Microcosms of Constructed Wetlands. Sustainability 2018, 10, 1594. [CrossRef]

42. Kochi, L.Y.; Freitas, P.L.; Maranho, L.T.; Juneau, P.; Gomes, M.P. Aquatic Macrophytes in Constructed Wetlands: A Fight against Water Pollution. Sustainability 2020, 12, 9202. [CrossRef]

43. Yasar, A.; Tabinda, A.B. Anaerobic treatment of industrial wastewater by UASB reactor integrated with chemical oxidation processes: An overview. Pol. J. Environ. Stud. 2010, 19, 1051-1061.

44. Powar, A.A.; Kore, V.S.; Kore, S.V.; Kulkarni, G.S. Review on application of UASB technologyfor wastewater treatment. Int. J. Adv. Sci. Eng. Technol. 2013, 2, 125-133. 
45. Musa, M.A.; Syazwani, I.; Hasfalina, C.M.; Norsyahariati, N.; Daud, N. Effect of Organic Loading Rate on Anaerobic Digestion Performance of Mesophilic (UASB) Reactor Using Cattle Slaughterhouse Wastewater as Substrate. Int. J. Environ. Res. Public Health 2018, 15, 2220. [CrossRef] [PubMed]

46. Musa, M.A.; Syazwani, I.; Harun, M.R.; Malek, A.; Wahab, A. A Comparative Study of Biogas Production from Cattle Slaughterhouse Wastewater Using Conventional and Modified Upflow Anaerobic Sludge Blanket (UASB) Reactors. Int. J. Environ. Res. Public Health 2020, 17, 283. [CrossRef]

47. Van Lier, J.B.; Vashi, A.; van der Lubbe, J.; Heffernan, B. Anaerobic Sewage Treatment Using UASB Reactors: Engineering and Operational Aspects. In Environmental Anaerobic Technology: Applications and New Developments; Fang, H.H.P., Ed.; Imperial College Press: London, UK, 2010; p. 420.

48. Hampannavar, U.S.; Shivayogimath, C.B. Anaerobic treatment of sugar industry wastewater by upflow anaerobic sludge blanket reactor at ambient temperature. Int. J. Environ. Sci. 2010, 1, 631-639.

49. Vieira, S.M.M.; Souza, M.E. Development of technology for the use of the UASB reactor in domestic sewage treatment. Water Sci. Technol. 1986, 18, 109-121. [CrossRef]

50. Chernicharo, C.A.L.; Almeida, P.G.S.; Lobato, L.C.S.; Couto, T.C.; Borges, J.M.; Lacerda, Y.S. Experience with the design and start up of two full-scale UASB plants in Brazil: Enhancements and drawbacks. Water Sci. Technol. 2009, 60, 507-515. [CrossRef] [PubMed]

51. Cosoli, P.; Sandri, A.; Paolazzi, F.; Rada, E.C.; Ragazzi, M. Wastewater treatment and disposal in Mahajanga, MadagascarScientific, Multidisciplinar cooperation. UPB Sci. Bull 2015, 77, 301-310.

52. Ragazzi, M.; Catellani, R.; Rada, E.C.; Torretta, V.; Salazar-Valenzuela, X. Management of urban wastewater on one of the Galapagos Islands. Sustainability 2016, 8, 208. [CrossRef]

53. Khalil, N.; Sinha, R.; Raghav, A.K.; Mittal, A.K. UASB Technology for Sewage Treatment in India: Experience, Economic Evaluation and Its Potential in Other Developing Countries. In Proceedings of the 12th International Water Technology Conference, IWTC12, Alexandria, Egypt, 27-30 March 2008; pp. 1411-1427.

54. Investigación y Desarrollo. Common Weed Revealed to Diminish Water Pollution. Available online: www.sciencedaily.com/ releases/2015/03/150313083400.htm (accessed on 24 November 2020).

55. APHA-American Public Health Association. Standard Methods for the Examination of Water and Wastewater, 21st ed.; American Public Health Association: Washington, DC, USA, 2005.

56. EPA. Waste Water Treatment Manuals Primary, Secondary and Tertiary Treatment; Environmental Protection Agency Ardcavan: Wexford, Ireland, 1997; ISBN 1899965467.

57. Lavrnic, S.; Pereyra, M.Z.; Cristino, A.; Cupido, D.; Lucchese, G.; Pascale, M.R.; Toscano, A.; Mancini, M. The Potential Role of Hybrid Constructed Wetlands Treating University Wastewater-Experience from Northern Italy. Sustainability 2020, $12,10604$. [CrossRef]

58. Herrera-Meliàn, J.A.; Mendoza-Aguiar, M.; Guedes-Alfonso, R.; Garcia-Jimenez, P.; Carrasco-Acosta, M.; Ranieri, E. Multistage Horizontal Subsurface Flow vs. Hybrid Constructed Wetlands for the Treatment of Raw Urban Wastewater. Sustainability 2020, 12, 5102. [CrossRef] 